\title{
Caso clínico 2. ¿Cuál sería su enfoque terapéutico?
}

\section{Clinical Case 2. What would be your therapeutic approach?}

Jaime Andrés Cajigas ${ }^{1}$

\author{
${ }^{1}$ Clínica de Marly, Bogotá, Colombia \\ Urol Colomb 2019;28:320.
}
Address for correspondence Jaime Andrés Cajigas, Especialista en Urología, Clínica de Marly, Bogotá, Colombia (e-mail: Platajacajigas@hotmail.com).

\section{Resumen \\ Palabras-clave \\ - frecuencia cardiaca \\ - presión arterial}

Paciente de 46 años, sexo femenino, con dolor abdominal, se encuentra el siguiente hallazgo.

46 years old female patient with abdominal pain, present some findings.
La paciente con frecuencia cardiaca de 82 y presión arterial de 130/84 sin ningún otro hallazgo (-Figs. 1 y 2).

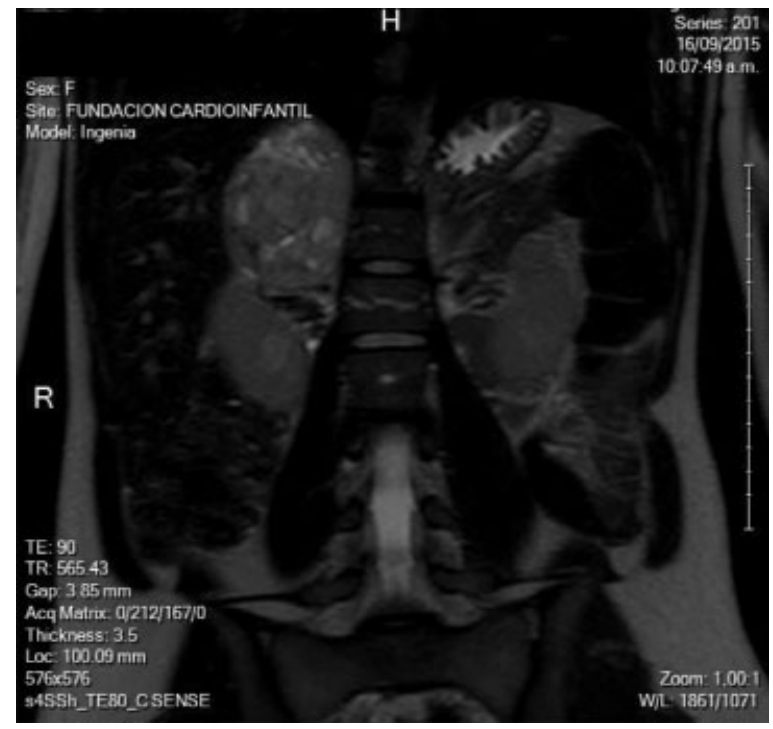

Fig. 1 Resonancia 1.

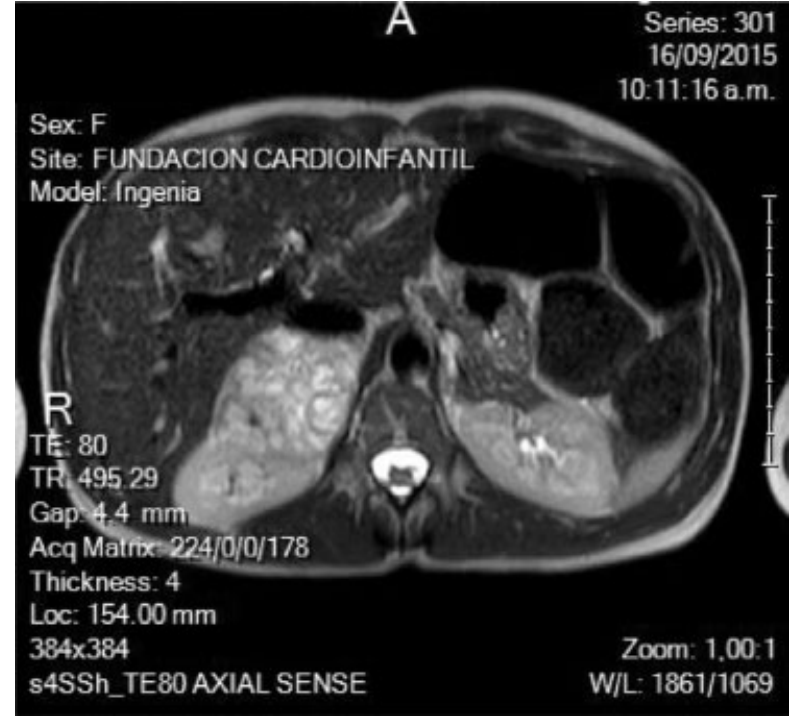

Fig. 2 Resonancia 2.

Copyright (c) 2018, Sociedad Colombiana License terms de Urología. Publicado por Thieme Revinter Publicações Ltda., Rio de Janeiro, Brazil. Todos los derechos (c) (i) $\ominus$ () I0.1016/j.uroco. e ISSN 2027-0119. reservados. 